\title{
Evaluation of the Sustainability of Energy Retrofit Interventions on the Historical Heritage: A Case Study in the City of Matera, Italy
}

\author{
Valeria Selicati $^{*}$, Nicola Cardinale ${ }^{1}$, Michele Dassisti $^{2}$ \\ ${ }^{1}$ Department of European and Mediterranean Cultures, University of Basilicata, Via Lanera, 75100 Matera, Italy \\ ${ }^{2}$ Department of Mechanics Management and Mathematics, Polytechnic of Bari, Viale Japigia 182, 70126 Bari, Italy
}

Corresponding Author Email: valeria.selicati@unibas.it

https://doi.org/10.18280/ijht.380103

Received: 19 November 2019

Accepted: 17 February 2020

\section{Keywords:}

energy retrofit, impact assessment, life cycle assessment, sustainability, historical buildings

\begin{abstract}
For some years now the regulations in the sustainability field oriented the practitioners towards an increasing restraint concerning energy necessities, to reconsider the weight in terms of energy and environmental impacts associated with different phases of their life cycle.

Among the reliable models to carry out the valuation, the Life Cycle Assessment remains a useful tool that determine the most impactful stages of the life cycle of any process and, thus, its environmental performances.

This paper aims to develop and complete previous analyses on sustainability led on the historical heritage of the city of Matera, highlighting all the issues that are still unresolved and the possible solutions to be undertaken.

Deep considerations on sustainability and its peculiarities are carried out. A reported analysis of literature and a description of the methods and tools used in the case study are shown.

The case study consists in performing the LCA using SimaPro software, based on the assumptions aimed to the energetic retrofit for "Palazzo del Sedile", an historical building located in Matera, Italy. In this section, three methods of assessment are largely described, the choice has been made due to their significance in expressing the environmental effects from three very different perspectives.
\end{abstract}

\section{INTRODUCTION}

Starting from the work carried out and published in the proceedings of the AIGE IIETA Congress on TI-IJES on June 2019 [1], the following text is an extension and completion of the considerations and the analysis implemented in the paper.

In the European Union the construction industry is responsible for about $42 \%$ of the final energy consumption and $50 \%$ of raw materials, produces approximately $35 \%$ of greenhouse gas emissions and $50 \%$ of waste $[2,3]$.

In this context, the Directive n. 2010/31/EU on building energy performance (EPBD recast), the European Union "is committed to develop a sustainable energy system, competitive, secure and decarbonized by 2050"; in particular, the Directive provides that by 31 December 2020 all new buildings must be "nearly zero energy buildings" [4].

The construction sector plays a prominent role and it responsible for the highest impact on the environment in terms of consumption of resources, energy consumption, emissions and wastes.

Also in the latest review of the Directive (July 2018) [5] it is evident that each UE member has the task of identifying a long-term strategy to support the renovation of residential and non-residential buildings, both public and private, in order to achieve a decarbonized and energy efficient real estate stock by 2050, facilitating the cost-effective transformation of existing buildings into nearly zero energy buildings, which is interpreted into the need to implement solutions that reduce energy needs and wastes especially in the use phase [6].

A first mention of the importance of the energy diagnosis relating to historical buildings was set up by the AiCARR (Italian association for air conditioning heating and refrigeration), which in February 2014 published a guide. For the evaluation and improvement of the energy performance of historic buildings, in accordance to the recent legislation [7].

After the widespread consolidation of energy efficiency, the interest of the market and the operators switched to environmental sustainability.

The demand for reliable indicators easy to use for environmental assessment of buildings has led in recent years to the development of several tools with very different approaches.

In particular, the first approach, voluntary, led to the definition of a multi-criteria rating systems (Green Building Rating Systems) that attach to each criterion a score, according to its performance. The scores are based on a weak sustainability where the final evaluation comes out from the idea that lower environmental performance achieved in a category can be offset by better environmental performance achieved in another category.

The regulatory path, however, is based on a Life Cycle Thinking approach, i.e. the quantification of synthetic environmental indicators using the Life Cycle Assessment method, internationally recognized as a method to evaluate the environmental profile of products, encoded within international regulations and promoted by European 
environmental policies. This approach points to a strong sustainability in order to verify the reduction of all environmental impact at each stage of the life cycle of the building and its components [8].

In this spirit, the scoring systems are progressively integrating environmental criteria within the LCA.

The LCA (Life Cycle Assessment) method is the most internationally accredited assessment for the quantification of the damage and its outcomes can be immediately related to impacts on human health, ecosystem quality and consumption of natural resources [9-19].

The aim of this paper is to develop and complete previous analyses on sustainability led on historical heritage, highlighting all the issues that are still unresolved and the possible solutions to be undertaken. The historical building case of study named "Palazzo del Sedile" is located in the old town of Matera, Basilicata, Italy.

The LCA is carried out with the SimaPro Software by PRé Consultants v.8.5.2.

The deep knowledge of the energetic-environmental skills of the historical heritage of the Mediterranean area of southern Italy is crucial in order to keep unaltered their identity and their original raison d'être for which they were built. While managing to make improvements in terms of thermohygrometric wellbeing and environmental quality, in view of environmental sustainability and planning of the best intervention strategies.

In literature, few are the data related to the sustainability or to the energy performance of the buildings that belong to the historical patrimony of the city of Matera [20-22].

In fact, there are only studies related to the evolution history of the City [23] or related to the structural preservation of the "Sassi" [24, 25], or simply manuals [26].

\section{LIFE CYCLE ASSESSMENT}

\subsection{Brief Synopsis of LCA and its regulations}

The LCA is an objective and reliable methodology to get a comprehensive and holistic approach of assessing environmental damage related to the building even when it is used to support decision making for the definition of policies strategic in this sector.

However, as a detailed LCA study can sometimes be burdensome in economic and time terms and complex to carry out (a considerable amount of environmental data must be acquired during each phase of the life cycle, and knowing in depth both the standardized methodology and the support tools such as software and databases), are increasingly developing "Simplified LCA" tool [27, 28] that allow an immediate assessment of life cycle of the products even by those who are not familiar with the skills and resources necessary to carry out a detailed study [29].

The origin of the LCA can be traced back to the early sixties with the publication of studies related to energy loads associated with some industrial productions. In this period an approach that embraces the entire life cycle, the so-called "Environmental Life Cycle Thinking", began to make its way. In the following decade, the problem exhaustibility of raw materials and energy resources encouraged further studies, mainly focused on optimizing the management of energy resources.

Between the late sixties and early seventies, there was a gradual transition from analysis focused mostly on energy consumption to analysis which considered both the consumption of raw materials and energy resources. Representative of this period are two important reports in which they tried to predict what would be the effects of a growing world population on the demand for raw materials and energy: "The Limits to Growth" by Meadows et al. in 1972 and "A Blueprint for Survival" by Goldsmith et al. always in 1972 .

Also, during this period was introduced the "from cradle to grave" approach, quantifying the use of resources and the release of pollutants into the environment throughout the product life cycle. The quantification of resources' consumption and environmental impacts of the products developed under the name of REPA (Resource and Environmental Profile Analysis) in the United States, while in Europe it was called eco-balance [30].

In the late seventies, emerged the concept of "sustainable development" and at the same time in Europe was published the "Handbook of Industrial Energy Analysis" by Bounstead and Hancock (1979), a milestone in the history of LCA methodology in that it was the first document to offer a description of an operational nature of the analytical procedure which is to be considered a fundamental part of the present technique [31]

SETAC in "Guideline for Life-Cycle Assessment: a code of practice" paper provided the most complete definition of LCA [32]: "A process to evaluate the environmental burdens associated with a product, process, or activity by identifying and quantifying energy and materials used and wastes released to the environment; to assess the impact of those energy and material uses and releases to the environment; and to identify and evaluate opportunities to effect environmental improvements".

At European level, in 2005 it was established the European Platform on the Evaluation of the Life Cycle coordinated by the Institute for Environment and Sustainability of the JRC (Joint Research Center) of the European Commission and the Directorate-General for Environment.

Among the most important works of this partnership is the publication in 2010 of ILCD Handbook (International Reference Life Cycle Data System) [33], which facilitates the use of ISO standards in the field of LCA, investigating various aspects of the methodology.

The strategic importance of adopting the LCA methodology as a basic and scientifically suitable tool for identifying significant environmental aspects is clearly expressed within the COM 2001/68/EC Green Paper and the COM 2003/302/EC on Integrated Product Policy, and is suggested, at least indirectly, also within the European EMAS (1221/2009) and Ecolabel (66/2010) regulations.

For instance, a promising possibility is the integration of building systems LCA data per functional unit in the Building Information Modelling (BIM) platform [34].

The national and international standard guidance for LCA studies is mostly represented by the ISO series:

1) UNI EN ISO 14040 (2006) "Environmental Management - Life cycle assessment - Principles and framework";

2) UNI EN ISO 14044 (now updated to 2018) "Environmental Management - Life cycle assessment Requirements and guidelines";

3) ISO 21931-1 (2010) "Sustainability in building construction-Framework for methods of assessment of the environmental performance of construction works Buildings"; 
4) UNI EN 15978 (2011) "Sustainability of construction works-Assessment of environmental performance of buildings - Calculation method" [35].

\subsection{Methodology}

LCA is an environmental assessment methodology applicable in any industrial or service sector that provides a comprehensive and detailed view of the system in order to:

- highlight and detect opportunities for the reduction of environmental impacts linked to the life of products;

- support decision making on interventions on processes, products and activities and compare the effects of different environmental policies and resource management;

- establish the initial step for a possible environmental declaration of EPD product;

- support marketing and environmental communication;

- comparing products and their emission with the same function.

The modern structure of the LCA proposed by ISO 14040 series consists of four main phases [36]:

o Goal and scope definition (ISO 14041): which products are considered, the definition of the functional unit, the boundaries of the system, the assumptions and limits, the methods and them motivations, to whom the study is addressed.

o Life Cycle Inventory analysis, LCI (ISO 14041): collection of data and calculation procedures aimed at quantifying the relevant incoming and outgoing flows of a product system, according to the goal and scope.

o Life Cycle Impact Assessment, LCIA (ISO 14042): assess the extent of potential environmental impacts using the outcomes from the life cycle inventory analysis.

o $\quad$ Life Cycle Interpretation (ISO 14043): a systematic procedure aimed at identifying, qualifying, verifying and evaluating the results of the inventory and impact assessment phases, in order to show them in such a way as to meet the requirements of the application described Objective and scope, and to draw conclusions and recommendations.

It is interesting that originally, an LCA study was composed of three phases: Inventory or data collection; Interpretation, to connect data to environmental impacts; Improvement of the system through different tests and scenarios. These 3 phases were the basis of the first ISO standards on LCA (from 14040 to 14043 , years $1997-98$ ) replaced in 2006 by the new ISO 14040 series and ISO 14044. In These years there have been many tools of calculation, software and manuals based on the indications and procedures of the ISO standards and which have made LCA a standardized methodology and therefore usable widely.

These developments mean that LCA is not a completely defined methodology because research must go on, they serve reference databases, new methods for calculating environmental impacts and reference models for interpretation [37].

The LCA methodology, being born in the industrial field, in its application for the environmental assessment of buildings should consider the peculiarities of the construction industry. This peculiarity was also highlighted in a 2003 report of SETAC-Europe LCA on the state in the construction industry [38].

According to the requirements of UNI EN 15643 environmental assessment of a building over its life cycle should consider the following phases, better schematized in Figure 1:

- Production: finding raw materials, production processes, transport.

- Construction: the construction site transportation, installation.

- Use: consumption energy, maintenance, repair, replacement, retraining.

- End of Life: building demolition or disassembly, disposal, recycling and transportation of waste other.

\begin{tabular}{|c|c|c|c|c|c|c|c|c|c|c|c|c|c|c|c|c|}
\hline \multirow{2}{*}{\multicolumn{3}{|c|}{$\begin{array}{c}\text { Product / } \\
\text { Manufacture } \\
\text { Stage } \\
{[\mathrm{A} 1-\mathrm{A} 3]}\end{array}$}} & \multirow{2}{*}{\multicolumn{2}{|c|}{$\begin{array}{c}\text { Constructio } \\
\text { n Process } \\
\text { Stage } \\
\text { [A4-A5] }\end{array}$}} & \multicolumn{7}{|c|}{$\begin{array}{c}\text { Use } \\
\text { [B1-B7] }\end{array}$} & \multirow{2}{*}{\multicolumn{4}{|c|}{$\begin{array}{c}\text { End-of-Life Stage } \\
\text { [C1-C4] }\end{array}$}} & \multirow{3}{*}{ 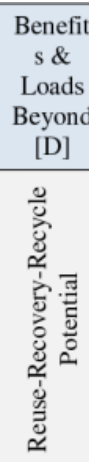 } \\
\hline & & & & & \multicolumn{5}{|c|}{ Building Fabric } & \multicolumn{2}{|c|}{$\begin{array}{l}\text { Operation } \\
\text { of the } \\
\text { Building }\end{array}$} & & & & & \\
\hline 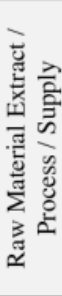 & 둥 & 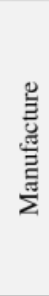 & 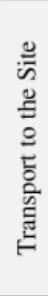 & 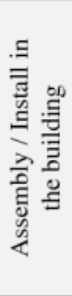 & 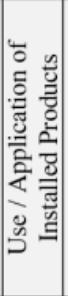 & $\begin{array}{l}\text { ญ } \\
\text { 플 } \\
\text { 플 }\end{array}$ & 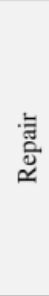 & 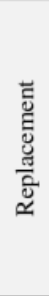 & 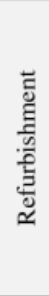 & 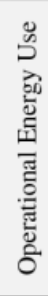 & 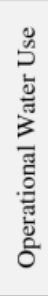 & 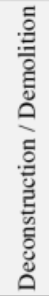 & 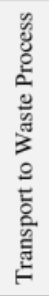 & 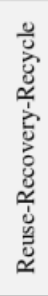 & 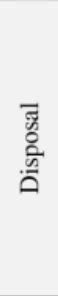 & \\
\hline A1 & $\mathrm{A} 2$ & A3 & A4 & A5 & B1 & B2 & B3 & B4 & B5 & B6 & B7 & $\mathrm{C} 1$ & $\mathrm{C} 2$ & $\mathrm{C} 3$ & $\mathrm{C} 4$ & D \\
\hline $\mathrm{Cra}$ & $30-0$ & & & & & & & Gat & & & & & & & & \\
\hline & & & & & & $\mathrm{Cra}$ & lle-to & Grav & & & & & & & & \\
\hline & & & & & & & & -10 & & & & & & & & \\
\hline & & & & & & & & $\mathrm{D}$ & & & & & & & & \\
\hline
\end{tabular}

Figure 1. Stages of the life cycle of a building in accordance with EN 15978 [39], image from [40]

\section{CASE STUDY}

The LCA has been executed using the software SimaPro by PRé Consultants v.8.5.2.0 on energetic retrofit interventions assumed for an historical building in Matera named "Palazzo del Sedile".
The data on energetic performances, especially about the assembly phase and use phase of life cycle, have been gotten from past realistic and accurate investigations carried out on the same building that were necessary for the drafting of the $\mathrm{PhD}$ thesis of the doctoral student Negro E. cited in the articles [20, 21, 41]. 
The information identified with the end of life phase were gotten from actual information and other relative investigations in literature [42-46].

\subsection{Description and location of the building}

The "Palazzo del Sedile" is an historical building located in the old town of Matera, a southern city of Italy. It was built in 1540 and now is owned by the Province of Matera.

In 1944 it has undergone to a change of use that made it a focal point for the city's musical heart becoming the main venue of the conservatory dedicated to the composer "Egidio Romualdo Duni".

From the early ' $80 \mathrm{~s}$, the underground levels of the building host a modern auditorium with a capacity of about 450 seats. Because of it, Piazza del Sedile can be considered the living room of the old town of Matera, bustling and busy always in the year. Nowadays it represents a place of identification, aggregation and sociability.

The current structure dates to the restoration works in 1779 where the mezzanine floor was constructed ex novo and the underground floor was renovated.

The mezzanine floor has a pentagon shape. An atrium connects the rooms on the ground floor to those on the first floor. The mezzanine floor presents seven rooms composed of Administration services and toilets.
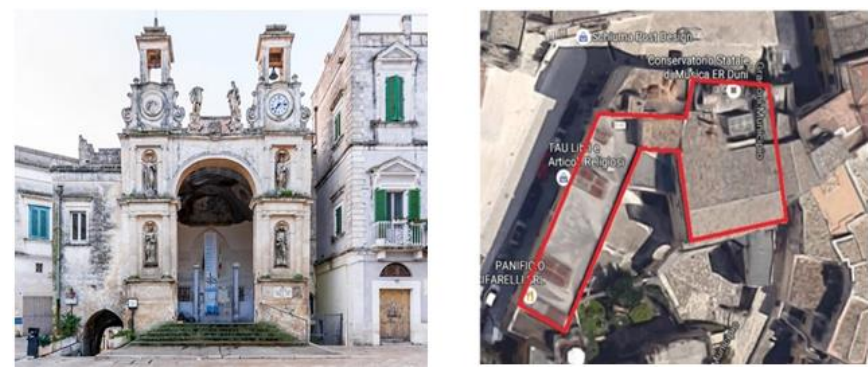

Figure 2. Entrance façade of Palazzo del Sedile in Sedile's Square and a view from above

The plant has an area of about $345 \mathrm{~m}^{2}$; the heights vary from $2.40 \mathrm{~m}$ up to $5.05 \mathrm{~m}$ (when there are vaults). Similar situation is found on the first floor made up of thirteen rooms divided into classrooms and toilets. About ninety people between students and staff attend the building. Its total area is about 590 $\mathrm{m}^{2}$ and the heights flow from $2.60 \mathrm{~m}$ up to $6.70 \mathrm{~m}$ at the top of the vaults. The rooms with flat floors have a height of $3 \mathrm{~m}$.

The mezzanine floor facing west has different characteristics from the central body of the building, as it shown in Figure 2 and in the 3D model in the Figure 3: the two parts were constructed in different periods, with different styles of construction, and this makes the energy performance of these two parts of the building quite different.

The bearing structure of the building consists of thick masonry septa (net of plaster) with variable width between 80 $\mathrm{cm}$ and $100 \mathrm{~cm}$ for the external walls, and between $40 \mathrm{~cm}$ and $60 \mathrm{~cm}$ for the internal ones. The interior floors consist of blocks in limestone as well as the roof covering. The waterproofing is made with tar and bricks in walkable floors and tiles in the areas with pitched roof.

In Table 1, the general parameters recorded in the $\mathrm{PhD}$ thesis [47], and useful in order to implement the LCA, are given.
Table 1. General parameters of Palazzo del Sedile

\begin{tabular}{|c|c|c|}
\hline $\begin{array}{c}\text { Floors } \\
{[\mathbf{n} .]}\end{array}$ & $\begin{array}{c}\text { Total height } \\
{[\mathrm{m}]}\end{array}$ & $\begin{array}{c}\text { Gross volume } \\
{\left[\mathbf{m}^{3}\right]} \\
\end{array}$ \\
\hline 3 & 13 & 5,550 \\
\hline $\begin{array}{c}\text { Total area } \\
{\left[\mathbf{m}^{2}\right]}\end{array}$ & $\begin{array}{c}\text { Floor area } \\
{\left[\mathbf{m}^{2}\right]}\end{array}$ & $\begin{array}{c}\text { Opaque walls } \\
{\left[\mathbf{m}^{2}\right]}\end{array}$ \\
\hline 1,500 & 595 & 1,144 \\
\hline Transparent walls & Dispersant surface & $\mathbf{A} / \mathbf{V}$ \\
\hline$\left[\mathbf{m}^{2}\right]$ & {$\left[\mathbf{m}^{2}\right]$} & {$\left[\mathbf{m}^{2} / \mathbf{m}^{3}\right]$} \\
\hline 67 & 2,217 & 0.17 \\
\hline
\end{tabular}

\subsection{Implementation of life cycle assessment}

The energetic retrofit on the building case of study consists in interventions on the envelope, air conditioning and heating systems and lighting, which complies with the minimum requirements imposed by Ministerial Decree June 26, 2015 [48].

The retrofit interventions hypothesized on the building and the new energy consumptions savings are shown in Table 2.

With the combination of these intervention, Negro E. estimated energy savings in $\mathrm{kWh} /$ year for about $70 \%$ compared to current consumption. This estimate is very plausible because the analysis was carried out through data collection and investigation in situ, a modelling and dynamic simulation mode by Designbuilder software and EnergyPlus ${ }^{\mathrm{TM}}$.

Dynamic simulation is an extremely advanced method of calculation that allows to evaluate the energetic performance of a building considering the inertial effects of the casing and the plants. and is more accredited in the energy certification.

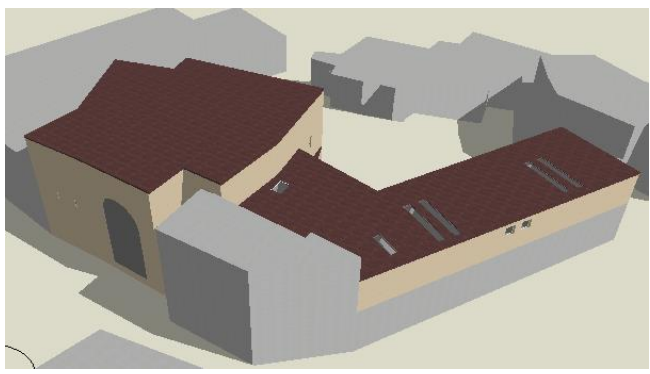

Figure 3. DesignBuilder model of Palazzo del Sedile

3.2.1 Goal and scope definition, system boundaries and functional unit

The definition of the boundaries of the system object of the study is an operation that depends on the goal of the study itself: the same system studied with different boundaries has different results.

The approach used for the case of study is "from gate to cradle", also considered as the "downstream module", which is the module that contains the product scenarios from the moment it leaves the gate of the manufacturer company and ends its "life" in transportation, use and end of life. LCA was assessed only on the retrofit interventions. According to EN 15978, A2 to D stages are assessed: in the whole life cycle, it was not considered only the raw materials stock and their assembly. The life cycle starts from the moment that the window or the insulating panel is transported to the construction site.

As functional unit it was decided to use the $\mathrm{m}^{2}$ floor area. 
This step is defined in SimaPro under the section "Goal and scope" recognizable in the left portion of software's GUI and includes: the description of LCA analysis that defines the author, developer, objective of the study, functional unit and the library (database) with its own specific field of application. The databases used for the case of study are Ecoinvent3, ELCD and Industry data 2.0 [49].

\subsubsection{Inventory Analysis (LCI)}

The inventory analysis is usually most delicate phase analysis of LCA and consists in the collection and quantification of incoming and outgoing flows for a given subsystem along the entire life cycle. The inventory analysis should provide a more complete and objective possible representation of reality and it is crucial the quality of data and information implemented in the model.

In the case study the system is divided into four subsystems corresponding to opaque walls, floors, windows, heating system. The lighting system is considered only as energy consumption in the use phase (see Table 2).

Table 2. Retrofit interventions and energy consumption savings

\begin{tabular}{|c|c|c|c|}
\hline Element & Before interventions & After intervention & $\begin{array}{c}\text { Savings } \\
{[\%]}\end{array}$ \\
\hline $\begin{array}{l}\text { Opaque } \\
\text { Walls }\end{array}$ & $\begin{array}{l}\text { Limestone wall of } 45-90 \mathrm{~cm} \text { and inner plaster of } 2 \mathrm{~cm} \\
\qquad U=0.63-1.12 \mathrm{~W} / \mathrm{m}^{2} \mathrm{~K}\end{array}$ & $\begin{array}{l}\text { Covering wall insulation with inner coat of } 5 \mathrm{~cm} \\
\text { Kenaf plate }(\lambda=0.038 \mathrm{~W} / \mathrm{mK}) . U=0.31 \mathrm{~W} / \mathrm{m}^{2} \mathrm{~K}\end{array}$ & 4 \\
\hline Roof slab & $\begin{array}{l}\text { Limestone roof of } 45 \mathrm{~cm} \text { externally covered with tiles } \\
\text { of } 1 \mathrm{~cm} \text { and internally covered with plaster of } 2 \mathrm{~cm} \\
\qquad U=1.042 \mathrm{~W} / \mathrm{m}^{2} \mathrm{~K}\end{array}$ & $\begin{array}{l}\text { Covering roof insulation with inner coat of } 9 \mathrm{~cm} \\
\text { Kenaf plate }(\lambda=0.038 \mathrm{~W} / \mathrm{mK}) . \mathrm{U}=0.25 \mathrm{~W} / \mathrm{m}^{2} \mathrm{~K}\end{array}$ & 13 \\
\hline Windows & $\begin{array}{l}\text { Wooden windows with double glass } 4 / 6 / 4 \text { or } 6 / 12 / 4 \\
\qquad U=3.15-1.78 \mathrm{~W} / \mathrm{m}^{2} \mathrm{~K}\end{array}$ & $\begin{array}{l}\text { PVC windows with low emissive double glass } 4 / 8 / 4 \\
\text { with } 8 \mathrm{~mm} \text { of argon interspace. } \mathrm{U}=1.71 \mathrm{~W} / \mathrm{m}^{2} \mathrm{~K}\end{array}$ & 20 \\
\hline $\begin{array}{l}\text { Heating } \\
\text { system }\end{array}$ & Boiler on the rooftop $\eta_{\mathrm{nd}}=0.81$ & $\begin{array}{c}\text { Stainless steel compression heat pump } \mathrm{COP}=3.08 \\
\text { and } \mathrm{P}=20 \mathrm{~kW} \text { and installation of thermostatic valves }\end{array}$ & 58 \\
\hline Lighting & $\begin{array}{l}\text { Metal Iodide spotlights, Neon 1x36 W; } \\
\text { Neon 2x36 W; Incandescent lamps }\end{array}$ & LED technology lamps & 91 \\
\hline
\end{tabular}

For the envelope it has been hypothesized a lifetime of 35 years, while for the heating system and lighting a duration of 15 years.

This decision has been made in relation to the fact that the retrofit interventions planned on Palazzo del Sedile are noninvasive and tend to just improve the energetic aspect of this historical building, which is outdated.

Not having studied in detail the thinkable incompatibility between old materials and new materials, it was decided to reduce the lifetime before the needing of further interventions [50].

For each material or element constituting the subsystem, there is a corresponding process and product stage to implement in SimaPro. These steps are included in SimaPro's GUI field "Inventory". The processes already implemented in software are grouped into categories and subcategories depending on the specific area to which they refer.

To build the life cycle of the product, the following product stages are available:

- Assembly: contains the list of all raw or semi-finished materials, which are necessary to produce one unit of the product and processes that define the consumption for assembling the same. For particularly complex products it is possible to decompose an "assembly" more "subassemblies", according to a modular logic;

- Life cycle: contains a connection assembly defined above or to the object of the analysis product, the processes relating to the use of the product (i.e., energy consumption), to one end of life scenario and any other life cycles, if the analyzed system is particularly articulated;

- Disposal scenario: contains the link to a series of processes, the description of the end of life of the analyzed system (i.e. landfill, reuse or recycling), and the respective percentages of the product that are devoted to them;

- Disassembly: lists the fractions in which is divided the product (which must necessarily be defined in more subassemblies) at the end of life with their disposal scenarios and treatment of residual waste;
- Reuse: it contains a list of processes that describe the environmental burden related to the operation of reuse and an assembly reference (or subassembly) object reuse.

In the use phase of case study, were considered the energy consumptions related to the lifetime of each subsystem described earlier, including lighting. Regarding the disposal scenario, it has been theorized the disassembly of the windows and the heat pump. The PVC material is intended for landfill, the glass to be recycled and the stainless steel of the pump will be melted and reused. All other waste by-products are sent to landfill. Clearly, also energy consumptions for the disposal and the transports of the material meant to be disposed were considered.

\subsubsection{Impact Assessment (LCIA) and interpretation}

From the LCI results, the impact assessment phase of the life cycle aims to assess the extent of potential impacts on human health and the environment. In particular, the inventory data is associated with specific categories of environmental impacts and category indicators. Moreover, LCIA provides information for the next phase of interpretation that aims to propose useful recommendations in relation to the goals and objectives of the study.

The interpretation stage may generate an iterative process of review and revision of the field of application of LCA, highlighting the limits and potential of the LCA methodology applied to the present case [36].

Figure 4 shows the tree that expresses the emissions in terms of energy consumption (red lines) or energy savings (green lines) for each phase and sub-phase with the corresponding line thicknesses that qualitatively represent the incidence of consumption or savings compared to the totality of the intervention: as it was logical to expect from the behavior of an historical building like Palazzo del Sedile, the LCA evaluation of the case study in all three methods of evaluation highlighted how the phase of use is the most significant, as it is considered a duration in years definitely longer than assembly and subsequent disposal phases. 


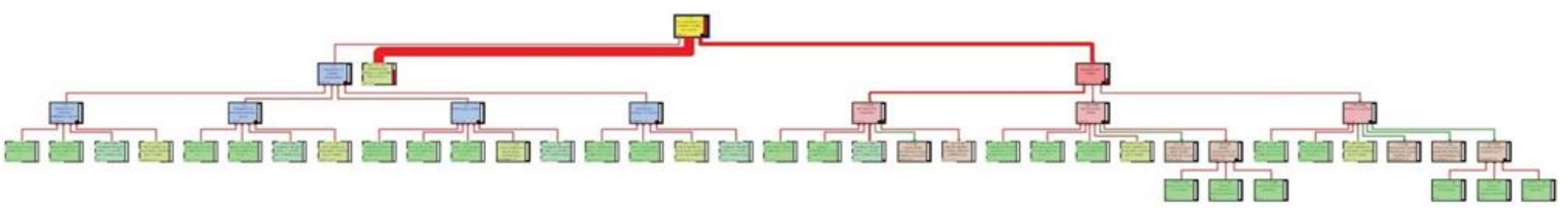

Figure 4. Tree representation of the entire LCA with Eco-indicator 99 method - cut off $0.1 \%$

It follows the disposal phase because a greater quantity of the retired materials is sent to landfill; it closes the list the transport and assembly of the elements because the interventions to be carried out are, as already said, noninvasive and aimed just at energy efficiency.

The assessment methods implemented in SimaPro for the case study are [51]:

Cumulative Energy Demand (CED): developed by Boustead \& Hancock in 1979, the method is used to quantify the energy consumption (expressed in $\mathrm{MJ}$ ) of a production system throughout the entire life cycle. This method considers five categories of impact: non-renewable energy, fossil; non- renewable energy, nuclear power; renewable energy, biomass; renewable energy, wind, solar and geothermal energy; renewable energy, hydropower.

In terms of primary energy to the assembly phase is associated an energy consumption amounted to $7.15 \%$ of the total, the use phase energy consumption equal to $75.65 \%$ and the disposal phase an energy consumption equal to $17.20 \%$ of the total. The normalized characterization according to the Italian energy mix provided by Italian GSE for the year 2017 [52] for impact categories is shown in Table 3 and the normalization for impact categories is shown in Figure 5.

Table 3. Impact categories of CED method

\begin{tabular}{cccccc}
\hline Category & Unit & Total & Assembly & Use & Disposal \\
\hline Non renewable, fossil & MJ & $7.73 \mathrm{E}+7$ & $5.55 \mathrm{E}+6$ & $5.85 \mathrm{E}+7$ & $1.33 \mathrm{E}+7$ \\
Non-renewable, nuclear & MJ & $5.07 \mathrm{E}+6$ & $3.64 \mathrm{E}+5$ & $3.84 \mathrm{E}+6$ & $8.72 \mathrm{E}+5$ \\
Non-renewable, biomass & MJ & $1.03 \mathrm{E}+6$ & $7.42 \mathrm{E}+4$ & $7.82 \mathrm{E}+5$ & $1.78 \mathrm{E}+5$ \\
Renewable, biomass & MJ & $3.97 \mathrm{E}+6$ & $2.85 \mathrm{E}+5$ & $3.00 \mathrm{E}+6$ & $6.83 \mathrm{E}+5$ \\
Renewable, wind, solar, & MJ & $1.74 \mathrm{E}+7$ & $1.25 \mathrm{E}+6$ & $1.31 \mathrm{E}+7$ & $2.99 \mathrm{E}+6$ \\
Renewable, water & MJ & $3.31 \mathrm{E}+7$ & $2.38 \mathrm{E}+6$ & $2.50 \mathrm{E}+7$ & $5.69 \mathrm{E}+6$ \\
\hline
\end{tabular}

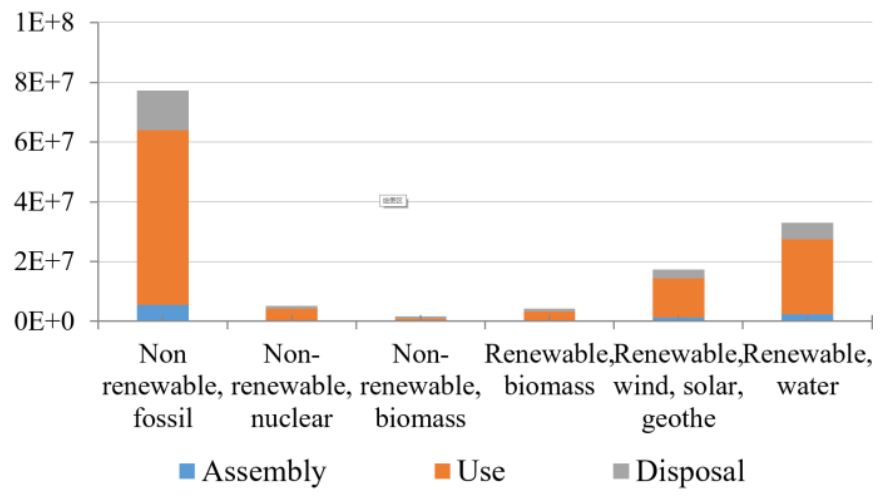

Figure 5. Normalization of CED method
Eco-indicator 99: developed in 1999 by Pré on behalf of the Dutch Ministry of Environment, is among the most popular in Europe; it constitutes a powerful tool for those who carry out the LCA analysis, as it allows to aggregate results in an easily understandable and usable units or numbers, called precisely Eco indicators. The method has been thought of in three versions depending on the goal and scope of the assessment:

- Egalitarian: considers all the possible impacts and their more catastrophic long-term effects;

- Individualist: considers the most scientifically proven impacts, potentially fixable by technology in the short term;

- Hierarchist: represents an intermediate vision between the two previous versions and includes impact categories aimed to balance the long-and short-term effects.

Table 4. Impact categories of Eco-indicator 99 method

\begin{tabular}{cccccc}
\hline Category & Unit & Total & Assembly & Use & Disposal \\
\hline Carcinogens & DALY & 1.64 & 0.14 & 1.3 & 0.21 \\
Resp. organics & DALY & $3.19 \mathrm{E}-3$ & $5.78 \mathrm{E}-5$ & $1.75 \mathrm{E}-3$ & $1.38 \mathrm{E}-3$ \\
Resp. inorganics & DALY & 4.03 & 0.1 & 2.79 & 1.14 \\
Climate change & DALY & 1.34 & 0.01 & 1.03 & 0.3 \\
Radiation & DALY & 0.04 & 0.02 & 0.02 & $1.4 \mathrm{E}-3$ \\
Ozone layer & DALY & $7.31 \mathrm{E}-4$ & $3.83 \mathrm{E}-6$ & $5.54 \mathrm{E}-4$ & $1.73 \mathrm{E}-4$ \\
Ecotoxicity & PAF*m $^{2} \mathrm{yr}$ & $5.53 \mathrm{E}+6$ & $3.18 \mathrm{E}+5$ & $3.87 \mathrm{E}+6$ & $1.34 \mathrm{E}+6$ \\
Acidification/Eutrophication & $\mathrm{PDF}^{*} \mathrm{~m}^{2} \mathrm{yr}$ & $1.13 \mathrm{E}+5$ & $1.92 \mathrm{E}+3$ & $8.76 \mathrm{E}+4$ & $2.3 \mathrm{E}+4$ \\
Land use & $\mathrm{PDF}^{*} \mathrm{~m}^{2} \mathrm{yr}$ & $1.3 \mathrm{E}+5$ & $1.62 \mathrm{E}+3$ & $7.4 \mathrm{E}+4$ & $5.43 \mathrm{E}+4$ \\
Minerals & MJ surplus & $2.09 \mathrm{E}+5$ & $4.52 \mathrm{E}+4$ & $8.56 \mathrm{E}+4$ & $7.86 \mathrm{E}+4$ \\
Fossil fuels & MJ surplus & $8.47 \mathrm{E}+6$ & $5.3 \mathrm{E}+4$ & $5.72 \mathrm{E}+6$ & $2.7 \mathrm{E}+6$ \\
\hline
\end{tabular}




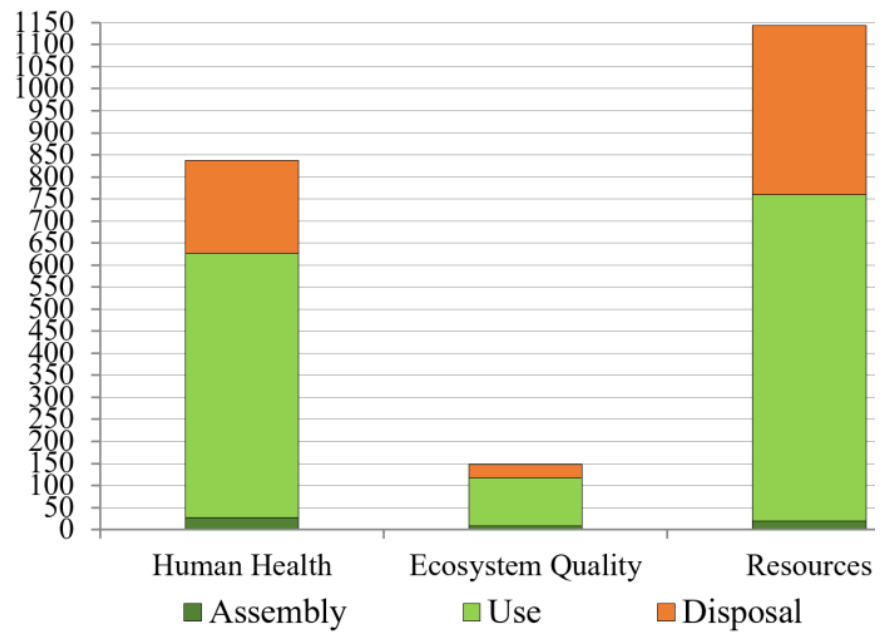

Figure 6. Normalization of Eco-indicator 99 method

The units of measurement associated with the categories of impact are respectively the DALY (number of disabilityadjusted life years or the burden of illness due to disability or premature death attributable to each disease), the PDF $\mathrm{m}^{2} \mathrm{yr}$ (Potentially Disappeared Fraction) or PAF $\mathrm{m}^{2} \mathrm{yr}$ (Potentially Affected Fraction), and the MJ surplus (surplus energy that it will be necessary to extract $1 \mathrm{~kg}$ of material at a time when the consumption of such material will be five times that extracted by humanity before 1990).

In terms of primary energy to the assembly phase is associated an energy consumption amounted to $2.83 \%$ of the total, the use phase energy consumption equal to $70.17 \%$ and the disposal phase an energy consumption equal to $27 \%$ of the total.

These results are quite different than Cumulative Energy Demand method. The characterization for impact categories is shown in Table 4 and the normalization for impact categories is shown in Figure 6.

EDIP2003: developed in Denmark in 1991 and aimed to embrace environmental implication also in industrial production. The method considers environmental impact, resource consumption and impacts in workplace as general damage categories and has 19 different impact categories each with its own unit of measurement. EDIP method distinguishes itself from other ones because its impact categories measure the causes and never the effects of a certain damage (equivalent emissions, $\mathrm{m} 3$ of polluted fluid and $\mathrm{kg}$ of waste produced). The main innovation lies in the consistent attempt to include exposure in the characterization modelling of the main non-global impact categories. EDIP2003 can be used both with and without spatial differentiation.

In terms of primary energy to the assembly phase is associated an energy consumption amounted to $2.32 \mathrm{E}+3 \mathrm{Pt}$ (9.75\% of the total), the use phase energy consumption equal to $1.7 \mathrm{E}+4 \mathrm{Pt}(71.43 \%$ of the total) and the disposal phase an energy consumption equal to $4.47 \mathrm{E}+3 \mathrm{Pt}(18.78 \%$ of the total). These results are quite similar to Cumulative Energy Demand method even if the impact categories are very different from each other with.

The characterization for impact categories is shown in Table 5. In the table are considered only the relevant values for the interpretation of the results. The normalization for the relevant impact categories is shown in Figure 7.

Table 5. Impact categories of EDIP2003 method

\begin{tabular}{cccccc}
\hline Category & Unit & Total & Assembly & Use & Disposal \\
\hline Global warming 100a & $\mathrm{kgCO}_{2} \mathrm{eq}$ & $6.44 \mathrm{E}+6$ & $6.07 \mathrm{E}+4$ & $4.94 \mathrm{E}+6$ & $1.44 \mathrm{E}+6$ \\
Ozone depletion & $\mathrm{kgCFC} 11 \mathrm{eq}$ & 0.76 & $3.69 \mathrm{E}-3$ & 0.59 & 0.17 \\
Ozone formation (Vegetation) & $\mathrm{m}^{2} \cdot \mathrm{ppm} \cdot \mathrm{h}$ & $3.11 \mathrm{E}+7$ & $5.16 \mathrm{E}+5$ & $2.19 \mathrm{E}+7$ & $8.67 \mathrm{E}+6$ \\
Acidification & $\mathrm{m}^{2}$ & $4.87 \mathrm{E}+5$ & $9.49 \mathrm{E}+3$ & $4 \mathrm{E}+5$ & $7.67 \mathrm{E}+4$ \\
Terrestrial eutrophication & $\mathrm{m}^{2}$ & $4.66 \mathrm{E}+5$ & $7.24 \mathrm{E}+3$ & $3.66 \mathrm{E}+5$ & $9.33 \mathrm{E}+4$ \\
Ecotoxicity soil chronic & $\mathrm{m}^{3}$ & $1.94 \mathrm{E}+8$ & $1.47 \mathrm{E}+8$ & $3.44 \mathrm{E}+8$ & $1.45 \mathrm{E}+8$ \\
\hline
\end{tabular}

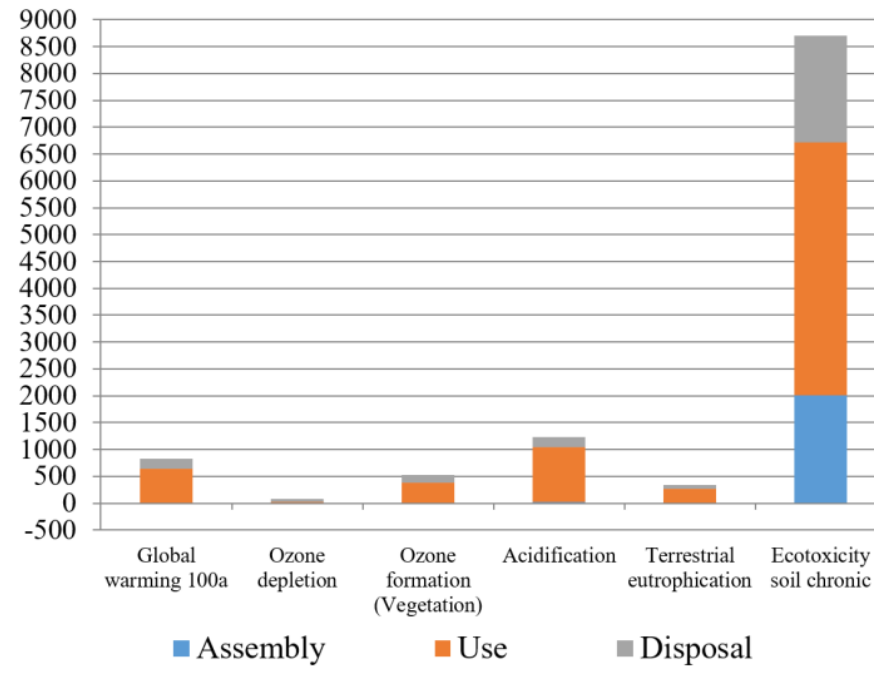

Figure 7. Normalization of EDIP2003 method

Weighting also, like the normalization step, is considered as an optional step according to the ISO standards. Weighting is the process of converting the results of the normalized indicators of the different impact categories into other values using numerical factors (weighting factors) based on subjective valuations dependent on the incorporation of social, political and ethical factors [53]. The weighting process consists of multiplying the weighting factors by the result of the normalization for each impact category, but it has not been considered in this paper.

\subsubsection{Brief comparison between the three methods}

These three methods are quite different, and it is very difficult to have a real numerical or statistical comparison. In general, depending on each methodology and the way by which the study is conducted (basic level, or an advanced level using software tools), when evaluating the impact assessment of a certain product and its corresponding components, the evaluation of each impact category and the calculation of the final impact score points is given by a common mathematical equation [54].

It is also true that the substantial difference between the methods implemented depends on the fact that within the LCIA step, two approaches of characterization can take place along the impact pathway of an impact indicator: midpoint approach and endpoint approach. Characterization at midpoint 
level models the impact using an indicator located somewhere along the methodology mechanism but before the endpoint categories; while characterization at the endpoint level requires modelling all the way until the endpoint categories described by the areas of protection (in most methodologies, the main areas of protection are eco system quality, human health and resources). EDIP 2003 is a midpoint-oriented method, Eco-indicator 99 is an endpoint-oriented method while Cumulative Energy Demand is categorized as "other based LCA methodology" because is focused just on energetic resources consumption (Table 6).

Table 6. Comparison between the outcomes of the three implemented methods

\begin{tabular}{cccc}
\hline & $\begin{array}{c}\text { Cumulative } \\
\text { Energy Demand }\end{array}$ & Eco-Indicator 99 & EDIP 2003 \\
\hline Assembly & $7.15 \%$ & $2.83 \%$ & $9.75 \%$ \\
Use & $75.65 \%$ & $70.1 \%$ & $71.43 \%$ \\
Disposal & $17.20 \%$ & $27 \%$ & $18.78 \%$ \\
\hline
\end{tabular}

Looking to the percentages of energy impact allocate in the three main phases of the life cycle, there is a further demonstration of how much each method has a weighing system characterized by a quantitative factor, but also by a subjective one: they give space to some aspects rather than others going to affect the weighing system.

By comparing the percentage allocations of environmental impact for the three main phases, it is possible to easily realize that there is a common framework in the calculations, otherwise it would not have been expected that the use phase was the most expensive one. But on the other hand, there is no consistency in the allocation of the importance of impacts.

Indeed, the deviation is not excessive, but considering that upstream of those percentages are sometimes very high values of primary energy, to a small percentage variation corresponds a substantial energetic one.

\subsection{System view}

An interesting reflection that is worth highlighting is the relationship between the energy savings and the economic efforts that involves the retrofit interventions. The normalized results are given in Table 7 which represents the system view.

This table provides the most important guideline for the interpretation phase of this work: it compares the environmental sustainability with another type of sustainability that represents the real benchmark for decisionmaking, especially if it hints the sphere of public administrations.

Table 7. System view

\begin{tabular}{cccc}
\hline & $\begin{array}{c}\text { Energetic } \\
\text { savings [\%] }\end{array}$ & $\begin{array}{c}\text { Economic } \\
\text { efforts [\%] }\end{array}$ & $\eta[\%]$ \\
\hline Opaque envelope & $12.29 \%$ & $48.27 \%$ & $3.23 \%$ \\
Windows & $14.81 \%$ & $21.21 \%$ & $8.87 \%$ \\
Heating system & $43.18 \%$ & $24.78 \%$ & $22.13 \%$ \\
Lighting system & $29.72 \%$ & $5.74 \%$ & $65.77 \%$ \\
\hline
\end{tabular}

The $\eta$ rate which numerically expresses the system view, represents the percentage ratio between the economic effort to carry out the interventions described above and the energy savings that such interventions would bring.

The table shows that the most useful profit, among all the interventions, is the lighting system as it represents a right compromise between energy savings and the estimated economic investment to be done in order to accomplish it. On the contrary, it is clear that the estimated investment to retrofit the opaque envelope is excessive compared to the energy saving that might entail.

This system view shows that even small measures to be studied at the design stage (just think of the type of insulation of HAVC system, or for example the conscious choice of the type of lighting system) can greatly influence the efficiency of an entire retrofit intervention both from a practical, energetic and economical point of view. It is important, therefore, to maintain the overall view of the system and its response in the short and long term on the timeline of the life cycle.

\section{CONCLUSIONS}

The specific aim of this paper is to provide to the reader an in-depth look at a work already presented to The 4th AIGE/IIETA International Conference and 13th AIGE 2019 Conference on "Energy Conversion, Management, Recovery, Saving, Storage and Renewable Systems" [1]; but he general aim of this paper, like the first one, is to promote the sustainable use of energy resources, environmental, natural, as an integral part of the design process or retrofit process.

The proposed guidelines could enable the operator of the sustainable and energetic sector to provide an indication about the maximum savings percentages obtainable in functions of the retrofit intervention on the buildings and their impact to the environment.

The environmental assessment tools (regulations, databases and software), in addition to the dynamic simulations of the building itself, are an excellent companion for achieving a sustainable result at 360 degrees.

The LCA is confirmed a reliable tool: it allows to highlight the environmental criticalities in the choice of materials and building elements, calculating the built-in energy and their different contribution to the global impact; this way it is possible to compare different components, evaluating the real environmental benefits of design solutions alternatives. It was possible to highlight how the processes of recycling and reuse of materials deriving allow to obtain significant environmental benefits during the disposal phase.

However, comparing more methods, it is perceived an important role to the subjectivity in the results, that is causes heterogeneity of the assessment that reduces the comparability of the LCA results and, therefore, causes a difficult univocal interpretation of the assessment [55].

The limits of LCA with SimaPro [56] are a prototypical character of the building sector, an increasing complexity of the process and its phases, highlighted by the interactions between the building and external factors, environment as well; also, the quantity of mini sub processes involved in a life cycle of a building and the difficulties in retrieving data compatible with the reality.

It is necessary to underline how the availability of an accessible and update database of materials and processes related to the Italian context, would increase the reliability and the significance of the results obtained.

Moreover, an increasing number of case studies relating to historical buildings located in Italy, it would allow a better comparability of results and the definition of environmental sustainability benchmark at national level. 
Finally, the great recommendation that the reader has to grasp, is that the system view represents a fundamental guideline to be used during each decision-making phase as it offers to environmental sustainability an additional interpretation key that is easier to interpret by any stakeholder.

\section{ACKNOWLEDGMENT}

This research was funded by FESTA Project from EU Horizon 2020 research and innovation programmed: Fostering Local energy investments in the Province of Matera, which promotes local energy investments for public buildings and disseminates the PPP (Public Private Partnerships) approach through innovative Energy performance contracts (EPC) in the regions.

The main partners were and still are the Province of Matera, which had the role of leader and coordinator of the project's activities, University of Basilicata - DICEM which had the role of technical partner for the scientific definition of ways and means, also innovative, that have been developed during the project and Local health care company of Matera (ASL Matera), owner of the hospital of Policoro.

\section{REFERENCES}

[1] Selicati, V., Cardinale, N., Rospi, G., Dassisti, M. (2019). Application of energetic life cycle assessment of retrofit interventions on the historical heritage: The case of "Palazzo del Sedile". TECNICA ITALIANA-Italian Journal of Engineering Science, 63(2-4): 235-242. https://doi.org/10.18280/ti-ijes.632-417

[2] Hauschild, M.Z., Rasmussen, F.N., Olsen, S.I. (2017). Life cycle assessment-theory and practice. In Life Cycle Assessment, 695-722. https://doi.org/10.1007/978-3319-56475-3

[3] European Commission. (2007). A Lead Market Initiative for Europe.

[4] Directive 2010/31/EU of the European Parliament and of the Council of 19 May, 2010 on the energy performance of buildings. Official Journal of the European Union, p. 23.

[5] Directive (EU) 2018844 of the European Parliament and of the Council of 30 May 2018 amending Directive 201031EU on the energy performance of buildings and Directive 201227EU on energy efficiency. http://data.europa.eu/eli/dir/2018/844/oj

[6] Sartori, I., Hestnes, A.G. (2007). Energy use in the life cycle of conventional and low-energy buildings: A review article. Energy and Buildings, 39(3): 249-257. https://doi.org/10.1016/j.enbuild.2006.07.001

[7] de Santoli, L. (2015). Guidelines on energy efficiency of cultural heritage. Energy Buildings, 86: 534-540. https://doi.org/10.1016/j.enbuild.2014.10.050

[8] Pombo, O., Rivela, B., Neila, J. (2019). Life cycle thinking toward sustainable development policy-making: The case of energy retrofits. Journal of Cleaner Production, 206: 267-281. https://doi.org/10.1016/j.jclepro.2018.09.173

[9] Russell, A., Ekvall, T., Baumann, H. (2005). Life cycle assessment introduction and overview. Journal of Cleaner Production, 13(13-14): 1207-1210. https://doi.org/10.1016/j.jclepro.2005.05.008
[10] Azapagic, A. (1999). Life cycle assessment and its application to process selection, design and optimisation. Chemical Engineering Journal, 73(1): 1-21. https://doi.org/10.1016/S1385-8947(99)00042-X

[11] Sharma, A., Kanbar, S., Atmaca, N. (2016). A review of studies on life cycle assessment of commercial buildings. 19th International Conference on Researches in Science \& Technology (ICRST), Barcelona, Spain.

[12] Zhang, H., Burr, J., Zhao, F. (2017). A comparative life cycle assessment (LCA) of lighting technologies for greenhouse crop production. Journal of Cleaner Production, 140: 705-713. https://doi.org/10.1016/j.jclepro.2016.01.014

[13] Li, H., Deng, Q., Zhang, J., Xia, B., Skitmore, M. (2019). Assessing the life cycle $\mathrm{CO}_{2}$ emissions of reinforced concrete structures: Four cases from China. Journal of Cleaner Production, 210: 1496-1506. https://doi.org/10.1016/j.jclepro.2018.11.102

[14] McGrath, T.E., Cox, S., Soutsos, M., Kong, D., Mee, L. P., Alengaram, J.U. (2018). Life cycle assessment of geopolymer concrete: A Malaysian context. In IOP Conference Series: Materials Science and Engineering 431(9): $\quad$ 092001. $\quad$ https://doi.org/10.1088/1757899X/431/9/092001

[15] Intini, F., Rospi, G., Cardinale, N., Kühtz, S., Dassisti, M. (2016). Life cycle assessment of Italian residential windows: Sensitivity of analysis. Int J Heat \& Tech, 34(S2):

S235-S241. https://doi.org/10.18280/ijht.34S207

[16] Le, A.T.H., Park, K.S., Domingo, N., Rasheed, E., Mithraratne, N. (2019). The 5th Annual Nzbers 2017 Advancing collaborative built environment research and practice. New Zealand. https://doi.org/10.1108/IJBPA01-2018-0009

[17] Ghisellini, P., Ripa, M., Ulgiati, S. (2018). Exploring environmental and economic costs and benefits of a circular economy approach to the construction and demolition sector. A literature review. Journal of Cleaner Production, 178: 618-643. https://doi.org/10.1016/j.jclepro.2017.11.207

[18] Meex, E., Hollberg, A., Knapen, E., Hildebrand, L., Verbeeck, G. (2018). Requirements for applying LCAbased environmental impact assessment tools in the early stages of building design. Building and Environment, 133: $228-236$. https://doi.org/10.1016/j.buildenv.2018.02.016

[19] Salzer, C., Wallbaum, H., Ostermeyer, Y., Kono, J. (2017). Environmental performance of social housing in emerging economies: Life cycle assessment of conventional and alternative construction methods in the Philippines. The International Journal of Life Cycle Assessment, 22(11): 1785-1801. https://doi.org/10.1007/s11367-017-1362-3

[20] Negro, E., Cardinale, T., Cardinale, N., \& Rospi, G. (2016). Italian guidelines for energy performance of cultural heritage and historical buildings: The case study of the Sassi of Matera. Energy Procedia, 97: 7-14. https://doi.org/10.1016/j.egypro.2016.10.008

[21] Rospi, G., Cardinale, N., Intini, F., Negro, E. (2017). Analysis of the energy performance strategies of school buildings site in the Mediterranean climate: A case study the schools of Matera city. Energy and Buildings, 152: 52-60. https://doi.org/10.1016/j.enbuild.2017.07.018

[22] Gizzi, F.T., Sileo, M., Biscione, M., Danese, M., de 
Buergo, M.A. (2016). The conservation state of the Sassi of Matera site (Southern Italy) and its correlation with the environmental conditions analysed through spatial analysis techniques. Journal of Cultural Heritage, 17: 6174. https://doi.org/10.1016/j.culher.2015.05.002

[23] Rota, L., Conese, F., Tommaselli, M., Cappiello, D. (1990). Matera: storia di una città. BMG.

[24] Cardinale, N., Rospi, G., Stefanizzi, P. (2013). Energy and microclimatic performance of Mediterranean vernacular buildings: The Sassi district of Matera and the Trulli district of Alberobello. Building and Environment, 59: $590-598$ https://doi.org/10.1016/j.buildenv.2012.10.006

[25] Giuffrè, A., Carocci, C. (1997). Codice di pratica per la sicurezza e la conservazione dei Sassi di Matera.

[26] Restucci, A. (1998). Matera: i Sassi: manuale del recupero. Elemond-Electa.

[27] Oregi, X., Hernandez, P., Gazulla, C., Isasa, M. (2015). Integrating simplified and full life cycle approaches in decision making for building energy refurbishment: benefits and barriers. Buildings, 5(2): 354-380. https://doi.org/10.3390/buildings5020354

[28] Lucchetti, M.C., Arcese, G., Traverso, M., Montauti, C. (2018). S-LCA applications: A case studies analysis. In E3S Web of Conferences, 74: 10009. https://doi.org/10.1051/e3sconf/20187410009

[29] Christiansen, K., Simplifying LCA: just a cut? / editor: K. Christiansen... Brussels, Belgium: Society of Environmental Toxicology and Chemistry - Europe, 1997. https://trove.nla.gov.au/work/33158031.

[30] Rigamonti, L., Fedele, A. (2017). L'analisi del ciclo di vita nel settore rifiuti: l'importanza di un solido approccio metodologico. Ingegneria dell'Ambiente, 4(3): 193-194.

[31] Dealy, J.M. (1980). Handbook of industrial energy analysis, I. Boustead and GF Hancock, John Wiley \& Sons, New York, 1979, 422 pages. \$69.50. AIChE Journal, 26(1):

174-174. https://doi.org/10.1002/aic.690260138

[32] Fava, J.A., Smerek, A., Heinrich, A.B., Morrison, L. (2014). The role of the Society of Environmental Toxicology and Chemistry (SETAC) in Life Cycle Assessment (LCA) development and application. In Background and Future Prospects in Life Cycle Assessment, 39-83. https://doi.org/10.1007/978-94-0178697-3_2

[33] Chomkhamsri, K., Wolf, M.A., Pant, R. (2011). International reference life cycle data system (ILCD) handbook: Review schemes for life cycle assessment. In Towards Life Cycle Sustainability Management, 107117. https://doi.org/10.1007/978-94-007-1899-9_11

[34] Bueno, C., Fabricio, M.M. (2018). Comparative analysis between a complete LCA study and results from a BIMLCA plug-in. Automation in construction, 90: 188-200. https://doi.org/10.1016/j.autcon.2018.02.028

[35] Thibodeau, C., Bataille, A., Sié, M. (2019). Building rehabilitation life cycle assessment methodology-state of the art. Renewable and Sustainable Energy Reviews, 103: 408-422. https://doi.org/10.1016/j.rser.2018.12.037

[36] UNI EN ISO 14040: 2006.

[37] Reap, J., Roman, F., Duncan, S., Bras, B. (2008). A survey of unresolved problems in life cycle assessment. The International Journal of Life Cycle Assessment, 13(5): 374. https://doi.org/10.1007/s11367-008-0009-9

[38] SETAC-Europe. (2003). Life-cycle Assessment in
Building and Construction: A State-of-the-art Report.

[39] European Committee for Standardization (CEN). EN 15978: Sustainability of construction works -Assessment of environmental performance of buildings -Calculation method, 2011.

[40] Kylili, A., Fokaides, P.A., Vaiciunas, J., Seduikyte, L. (2016). Integration of Building Information Modelling (BIM) and Life Cycle Assessment (LCA) for sustainable constructions. Journal of Sustainable Architecture and Civil Engineering, 13(4): 28-38. https://doi.org/10.5755/j01.sace.13.4.12862

[41] Rospi, G., Negro, E., Cardinale, T., Cardinale, N. (2017). Microclimate of territory of Matera and the heat island effect. Energy Procedia, 133: 2-15. https://doi.org/10.1016/j.egypro.2017.09.361

[42] Eberhardt, L.C.M., Birgisdóttir, H., Birkved, M. (2019). Life cycle assessment of a Danish office building designed for disassembly. Building Research \& Information, 47(6): 666-680. https://doi.org/10.1080/09613218.2018.1517458

[43] Moslehi, S., Reddy, T.A. (2019). An LCA methodology to assess location-specific environmental externalities of integrated energy systems. Sustainable Cities and Society, 46: 101425. https://doi.org/10.1016/j.scs.2019.101425

[44] Goldstein, B., Rasmussen, F.N. (2018). LCA of buildings and the built environment. In Life Cycle Assessment, 695-722. https://doi.org/10.1007/978-3-319-56475-3_28

[45] Schiavoni, S., Sambuco, S., Rotili, A., D’Alessandro, F., Fantauzzi, F. (2017). A nZEB housing structure derived from end of life containers: Energy, lighting and life cycle assessment. In Building Simulation, 10(2): 165181. https://doi.org/10.1007/s12273-016-0329-9

[46] Vitale, P., Arena, N., Di Gregorio, F., Arena, U. (2017). Life cycle assessment of the end-of-life phase of a residential building. Waste Management, 60: 311-321. https://doi.org/10.1016/j.wasman.2016.10.002

[47] Negro, E. (2018). Protocollo e linee guida per la riqualificazione energetica del patrimonio edilizio esistente della città di Matera, Doctoral dissertation, $\mathrm{PhD}$ Thesis in Cieties and Landscapes: Architecture, Archaeology, Cultural Heritage, History and Resources, Università degli Studi della Basilicata 279.

[48] Corrado, V., Ballarini, I., Dirutigliano, D., Murano, G. (2016). Verification of the new Ministerial Decree about minimum requirements for the energy performance of buildings. Energy Procedia, 101: 200-207. https://doi.org/10.1016/j.egypro.2016.11.026

[49] Goedkoop, M., De Schryver, A., Oele, M., Durksz, S., de Roest, D. (2008). Introduction to LCA with SimaPro 7. PRé Consultants, The Netherlands.

[50] Vilches, A., Garcia-Martinez, A., Sanchez-Montanes, B. (2017). Life cycle assessment (LCA) of building refurbishment: A literature review. Energy and Buildings, 135 , https://doi.org/10.1016/j.enbuild.2016.11.042

[51] PRé Consultants, B.V. (2008). SimaPro Database Manual Methods Library.

[52] Report GSE. Fuel mix, determinazione del mix energetico per gli anni 2017-2018. https://www.gse.it/servizi-per-te/news/fuel-mixdeterminazione-del-mix-energetico-per-gli-anni-20172018, accessed on 17 Nov. 2019.

[53] Powell, J.C., Pearce, D.W., Craighill, A.L. (1997). 
Approaches to valuation in LCA impact assessment. The international journal of life cycle assessment, 2(1): 11-15. https://doi.org/10.1007/BF02978709

[54] De Gracia, A., Rincón, L., Castell, A., Jiménez, M., Boer, D., Medrano, M., Cabeza, L.F. (2010). Life Cycle Assessment of the inclusion of phase change materials $(\mathrm{PCM})$ in experimental buildings. Energy and Buildings, 42(9):

$1517-1523$. https://doi.org/10.1016/j.enbuild.2010.03.022

[55] Rospi, G., dassisti, M., Intini, F., Giovannini, A. (2017). Reducing the life cycle assessment heterogeneity: A system design view. In 10th International Conference on Sustainable Energy and Environmental Protection Environmental Management and Impact Assessment.

[56] Asdrubali, F., Baldinelli, G., Battisti, M., Baldassarri, C. (2008). Analisi ed ottimizzazione energetico-ambientale di un edificio mediante la valutazione del ciclo di vita (LCA). Atti, 8: 355-360.

NOMENCLATURE

$\mathrm{U}$

COP

$\mathrm{P}$

A

V

\section{Greek symbols}

$\lambda$

$\eta_{\text {nd }}$

\section{Subscripts}

nd

global thermal transmittance, $\mathrm{Wm}^{-2} \mathrm{~K}^{-1}$

dimensionless coefficient

of performance

thermal power, $\mathrm{kW}$

area, $\mathrm{m}^{2}$

volume, $\mathrm{m}^{3}$

thermal conductivity, $\mathrm{Wm}^{-1} \mathrm{~K}^{-1}$

dimensionless average seasonal yield 